\title{
THE ROLE OF CONVENTIONAL RESEARCH METHODS IN INFORMATION SYSTEMS ACTION RESEARCH
}

\author{
Matt Germonprez \\ Case Western Reserve University \\ Lars Mathiassen \\ Georgia State University
}

\begin{abstract}
Action research has for many years been promoted and practiced as one way to conduct empirical research within the Information Systems discipline. While the approach can lead to highly relevant contributions, researchers are warned against the many risks involved in action research. Based on successful cases of Information Systems action research we explore the role played by conventional research methods in developing and presenting research contributions. The cases suggest that action research lends itself strongly toward multi-method approaches and facilitates the creation ofmulticontribution projects. We identify two approaches to mixing action research and conventional research methods-the planned and the emergent approaches - and we argue that action research can be adopted in ways that are no more risky than other conventional approaches to Information Systems research.
\end{abstract}

Keywords: Action research, IS research methodologies, pluralism

\section{INTRODUCTION}

In research, as in practice, we constantly balance the best methods to apply to questions and problems. We adopt methods because we have used them in the past, others have used them, and we know how to implement them, only to find out we can not answer all the questions we need to answer. To resolve this, we add additional 
methods for answering our remaining questions. While accepting findings from the first method, we often need more explanation than the first method could deliver. We therefore constantly run methods sequentially, in parallel, and even at different levels of analysis (Mingers 2001). We have an elaborate understanding of the use of singular research methods, the data they can produce, the questions they can answer, and how they can help develop a high quality contribution to scientific knowledge. We lack, however, a practical understanding of how research methods are mixed and how the use of multi-method approaches supports the researchers in identifying and developing several contributions within the same research project.

This paper explores this issue in the particular context of action research. Action research was chosen because of its support for both positivistic and interpretivistic approaches (Kock 1997b), however, the conclusions can be applied across varying epistemologies, ontologies, and methodologies (Walsham 1995). We build on the exemplar work of John Mingers (2001) on how to mix methods within the Information Systems discipline. We use Mingers' work as a framework to study methodological pluralism in IS and explain how pluralism is used to increase diversity in IS research. Our aim is twofold. First, we want to further our understanding of multi-method approaches to Information Systems research. Second, we want to contribute to a more practical understanding of how action research can be carried out within our discipline. Specifically we address the following research question: What is the role of pluralist methodology in action research within the Information Systems discipline?

Action researchers attempt to develop contributions that are relevant to practice by involving themselves in particular problem situations (Rapoport 1970). While this approach offers important opportunities for exploration and learning, it unfortunately leads to a number of pitfalls. Baskerville and Wood-Harper (1996) have summarized these as (1) lack of impartiality of the researcher; (2) lack of discipline; (3) mistaken for consulting; and (4) context-dependency leading to difficulty of generalizing findings. Many Information Systems researchers hesitate for these reasons to include action research in their repertoire ofresearch methods and younger colleagues are often warned against doing action research because it might slow down or damage their career. We argue in the following that action research lends itself strongly toward multi-method approaches and that a deeper understanding of the multi-method nature of action research can lead us to action research practices that are no more risky than other conventional approaches to Information Systems research.

Mingers proposes mixing methods as a solution for navigating the research process in moving from an original appreciation of a research project to action in implementing the findings. Where one methodology falls short along this path, another can succeed. Action research is sometimes used from the outset as a planned and dominant methodology through which research explanations are provided. Action research emerges in other situations as a useful complimentary method embedded into a larger research process. Drawing upon published cases of successful Information Systems research, we develop and discuss this distinction between planned and emergent method mixing involving action research. We show in particular how action research invites researchers to engage in additional empirical explorations or develop theoretical thinking based on existing findings. Action research facilitates for these reasons creation of multicontribution projects. 
After having reviewed the literature on action research and Mingers' framework for mixing research methods, the paper presents selected cases of planned and emergent approaches to method mixing involving action research. On that basis, we discuss the implied contributions to research methodology and practice within the Information Systems discipline.

\section{ACTION RESEARCH}

Information Systems action research is applied research to develop a solution that is of practical value to the people with whom the researchers are working, and at the same time to develop theoretical knowledge of value to a research community (Davison 1998, pp. 3-6). This definition is in line with classical definitions of action research (Rapoport 1970) and it directly addresses concerns by Gustavsen (1993), Levin (1993), and Kock et al. (1997) who state that action research must support both the production of practical outcomes as well as the production of research theory. Baskerville and Wood-Harper (1998) echo the dual outcome perspective of action research. They state that action research is embedded within a practical system it is being used to explain. Within this system, an "unstructured field experiment" takes place where researchers act as change agents to improve practical outcomes and describe a new state of affairs that result from the change (Baskerville and Wood-Harper 1998, p. 91).

Action research links theory and practice through a cyclic and often iterative process (Baskerville and Wood-Harper 1996; Checkland 1991; Hult and Lennung 1980; McKay and Marshall 2001; Susman and Evered 1978). There are many different ways to organize the cyclic process. The model of Susman and Evered (1978) captures well the general approach taken. According to them, action research is executed through one or more cycles of(1) diagnosing (identifying or defining a problem); (2) action planning (considering alternative courses of action for problem solving); (3) action taking (selecting and executing a course of action); (4) evaluating (studying the consequences of the action); and (5) specifying learning (identifying general learning).

Action research allows the researchers to tap directly into practical problem solving through organizational intervention, but it requires constant attention and specific skills to manage the process. There are pitfalls involved (Baskerville and Wood-Harper 1996) and the researchers are confronted with dilemmas related to issues of ethics, goals, and initiative (Rapoport 1970). Researchers need, for each dilemma, to balance a concern for the practical problem and their scientific interests. Leaning too strongly toward practical concerns the process will result in actions that are not theoretically informed and have no cumulative scientific effect. In the other extreme, the process leads away from actions that have relevant implications for the situation at hand. Avison et al. (2001) suggest that action research therefore raises control issues related to the initiation of projects, the authority for action, and the degree of formalization. They offer for each of these managerial concerns a variety of approaches to help structure action research efforts. McKay and Marshall (2001) suggest along the same lines that action researchers should conceive the process as consisting of two parallel, interacting cycles: the problem cycle (focused on the problematic situation) and the research cycle (focused on the scientific goals). This distinction helps researchers separate concerns, adopt appropriate problem solving and research methods, and manage the process toward the dual goals of action research. 
We argue in the following that these particular characteristics of action research lend themselves strongly to pluralist methodology and also that a deeper understanding of the multi-method nature of action research can help researchers design and manage their efforts in ways that lead to scientific progress without abandoning practical concerns.

\section{MIXING METHODS}

Without a strong handle on methodology, research questions cannot be framed, data cannot be analyzed, theory cannot be tested, and science cannot be informed. Specifically, a researcher's choice of method(s) impacts which conclusion can be drawn and it shapes the explanation of results (Kinkaid 1994; van Fraassen 1980; Orlikowski and Baroudi 1991; Salmon 1989). The practical use of methods incorporates researcher beliefs, it is a concrete manifestation of the ontology and epistemology of a field, and it ultimately impacts how research contributes to and shapes scientific paradigms. The question of which research method(s) to use is therefore of primary importance both to the individual researcher and to the continued development of our discipline.

Mingers (2001) offers two fundamental reasons for combining methods in Information Systems research. First, the world we are studying is multidimensional including the material world, the personal world, and the social world (Habermas 1984). To address and understand these different aspects of the world, we need a variety of research methods. Second, research is a process which involves rather different challenges and activities, which will predominate at different times as the process unfolds. To effectively address the challenges involved-including appreciation of the research situation, analysis of data, assessment of explanations, and action to report on or disseminate results (Mingers 2001) — the researcher needs different methods to help develop richer and more reliable results. As researchers move through objective, subjective, and intersubjective perspectives (Habermas 1984) and as they take part in appreciation, analysis, assessment, and action as part of the research process, they are advised to adopt methods across the epistemological perspectives that support the movement from appreciation to action. In doing so, they must balance between relying on tested methods and forging new methodological ground in the examination and explanation of new phenomena. Mingers addresses this thinking through five different types of multi-method research design:

- Sequential, where methods are applied in a sequence with results from one method feeding into the next

- Parallel, where methods are executed simultaneously with results being transferred between them

- Dominant, where one method is adopted as the main approach supplemented by other methods

- Multi-methodology, where different methods embodying different paradigms are combined and tailored to a particular project

- Multi-level, where the research simultaneously addresses different organizational levels using different methods 
Mixing methods requires in each of these cases certain skills to effectively manage the additional complexity within the research process. Researchers must, in Mingers' terms, know how to organize and manage the appreciation, analysis, assessment, and action activities by selecting and mixing a variety of research methods. They need, on a more concrete level, the specific strategies and tactics to practice multi-method research.

\section{ACTION RESEARCH CASES}

Sometimes researchers have a clear agenda of how they plan on using action research and mixing methods in a research process. Other times, researchers are contributing to a collection of studies, using an emerging set of methods to initiate explorations and provide explanations based on varied epistemological perspectives. We denote the former the planned approach where action research becomes an explicit instantiation of Mingers' research process of appreciation, analysis, assessment, and action. We denote the latter the emergent approach in which action research is embedded into a broader research context. Mingers' research process represents, in these cases, a meta-level framework that can explain and guide how different methods are selected and mixed in order to inform science and practice. We have explored 12 cases of successful action research within the Information Systems discipline. Three cases are represented in the following two sections to illustrate the planned and emergent approaches of mixing action research. Appendix A presents nine additional cases in summary form.

\subsection{The Planned Approach}

Researchers often turn to multiple methods in the examination and explanation of research questions. Action research can act as a platform on which explanation can be produced and additional methods can be adopted. Action research is then chosen and articulated as the primary method representing Mingers' research process. There is, from the outset, an overall contractual arrangement between a client (with some problematic situation) and the researchers. It is agreed that the collaboration will serve the double purpose of addressing the client's problematic situation while at the same time advancing scientific knowledge within certain disciplines (Rapoport 1970). The approach is fundamentally based on action research and other, supplementary research methods are adopted as needed.

Mathiassen and his colleagues used the planned approach to study software process improvement (SPI) in four software companies over a three-year period (Mathiassen 2002; Mathiassen et al. 2002). The dual purpose of this project was to improve software practices in four software organizations and at the same time to contribute to knowledge on software engineering and management. Haif a dozen researchers and nearly 40 practitioners participated and the project resulted in a number of contributions, including a book (Mathiassen et al. 2002), three Ph.D. dissertations, and more than 30 conference and journal papers. A few, selected publications illustrate how different research methods were adopted and mixed in this planned approach to action research (see Figure 1). 


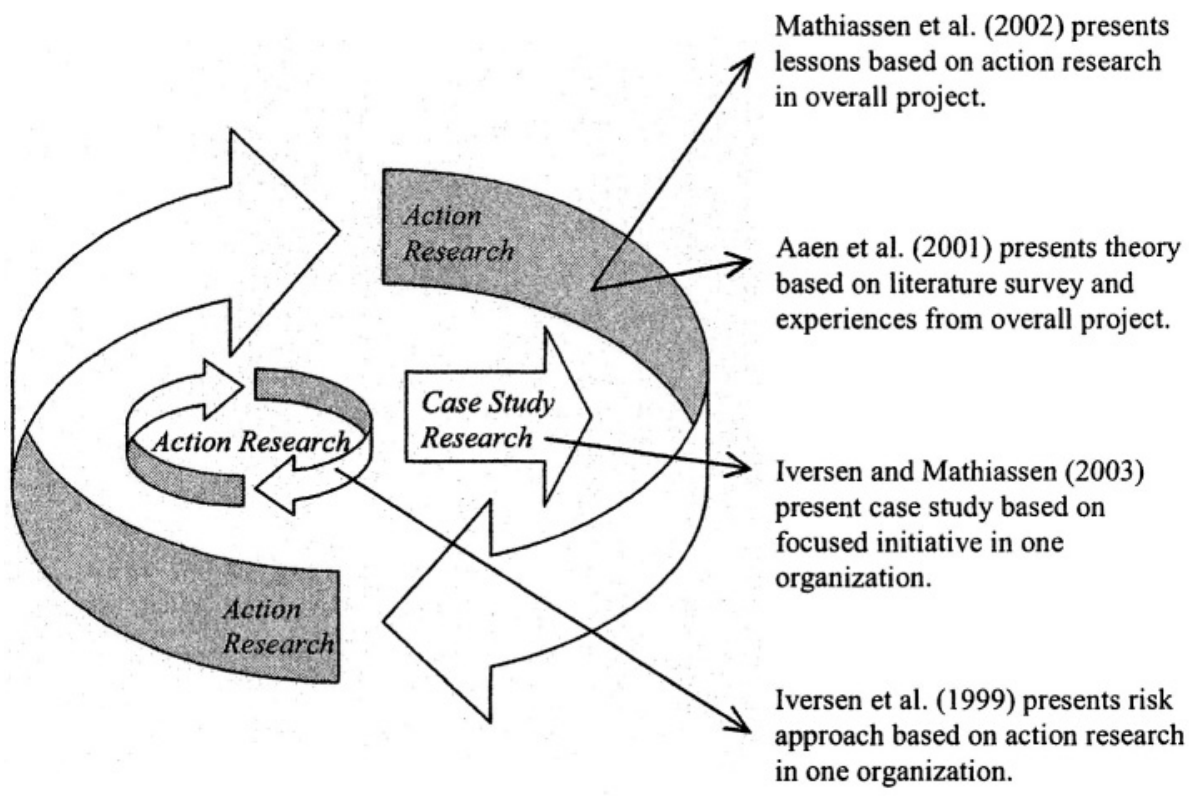

Figure 1. A Planned Approach to Action Research (Dominant)

Mathiassen et al. (2002) documents the action research in the four organizations. The book includes key lessons from each of the four software organizations together with contributions that focus on specific issues, e.g., assessment of software practices, adoption of knowledge management tactics in SPI, and practical approaches to process implementation. The book presents contributions from the overall project based on action research.

Aaen et al. (2001) offer a conceptual framework for understanding SPI theory and for assessing SPI strategies adopted by specific organizations. The SPI domain is broad with no agreed-upon understanding of the underlying assumptions and key ideas involved in this approach to improving software practices. Aaen et al. provide a conceptual framework based on a systematic survey of the SPI literature and informed by experiences from the four organizations. This publication represents theory development from the overall project based on literature studies and conceptualization of SPI practices in the four organizations.

Other publications were developed based on focused activities within the larger project. These publications emphasize particular issues related to SPI, they draw upon incidents in one or more of the four organizations, and they adopted a variety of theoretical frames and research approaches. Two examples illustrate this. Iversen and Mathiassen (2003) present a traditional case study based on interviews, documents, minutes of meetings, etc., in an attempt to design and implement a software metrics program in one of the four organizations. Action research played no role in the development of this particular publication, but the action research approach to the overall project created the opportunity for the involved researchers to identify and 
develop this research. Iversen et al. (1999) present an approach to manage risks in SPI projects. The risk management approach was developed in response to specific needs in one of the four software organizations. The opportunity to engage in this particular effort was again created by the overall action research approach. This time the researchers adopted action research for the specific, focused activity.

Action research was adopted as the overall guiding method in the examination of the research across the different contributions. The research process of Mingers (2001), moving from appreciation to action, was enacted through the cycles of action research, i.e., diagnose, plan, act, evaluate, and learn (Susman and Evered 1978). Based on this basic organization of the research process, activities were identified and launched both on the overall project level and within focused initiatives in one or more organization. These activities were based on a mix of research methods including literature surveys, case studies, field experiments, and focused action research efforts (Mathiassen 2002).

Action research served, in this case, as a platform upon which several focused studies were launched through a variety of research methods. Aaen et al. summarize and synthesize findings from a number of focused research activities (see Mathiassen et al. 2002) that were launched and executed in sequence and in parallel (Mingers 2001). The paper is an example of a multi-methodology research design in which literature survey, action research, and theory development are combined to serve the particular needs of this study. The overall SPI project exemplifies multi-level research design. It addresses software engineering and management practices on individual, project, and organizational levels using different methods.

Davison (1998) represents a different example of a planned approach. Action research was used from the outset in combination with case studies to explore how group support systems could be used to improve meeting processes in Hong Kong. Action research was in this case used repeatedly in parallel with case studies as illustrated in Figure 2. This combined approach answered the questions of "what and why?" through case studies and "how to?" through action research. Action research was required as a parallel methodology with case studies to help enact the roles of facilitator, leader, technician, and researcher for the group support systems (Davison 1998).

As with Mathiassen et al. (2002), Davison adopted a planned approach to action research from the very outset of this project. Action research played a dominant role in framing the overall process, but it was used in parallel with case studies and through a sequence of interventions targeting planning, training, and business process reengineering related to the improved use of group support systems.

\subsection{The Emergent Approach}

Action research can also be used, not as a planned and dominant methodology from the outset of a research initiative, but as a sequential methodology that emerges and proves helpful as the examination and explanation of the research phenomena unfolds (Mingers 2001). This approach is often evident across several studies embedded within a research discipline and, from the outset, there is no planning of how and when to mix methods across studies. 


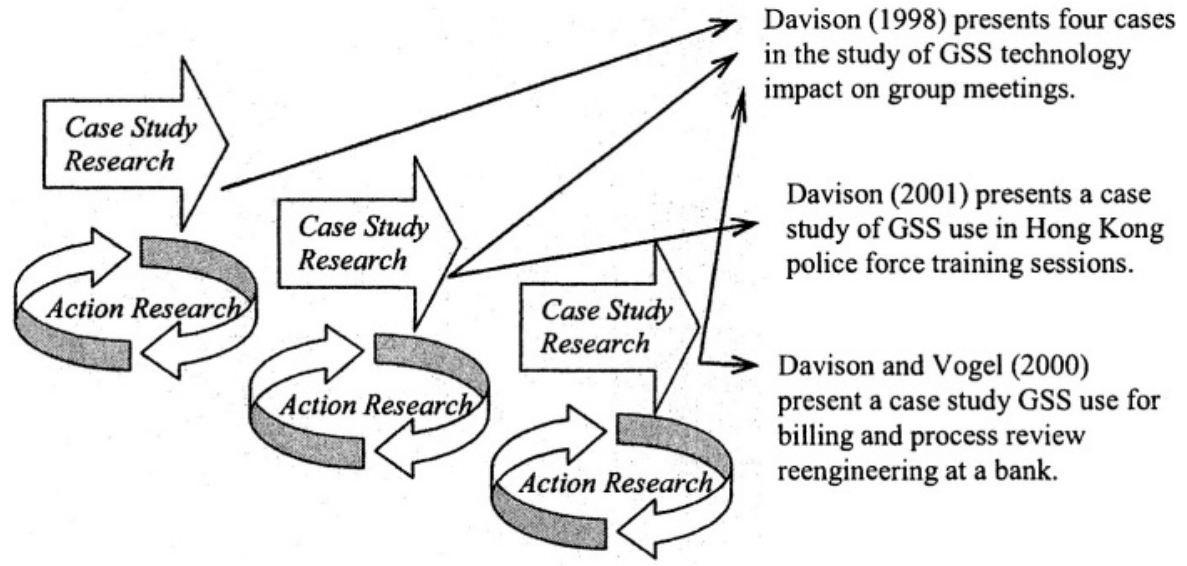

$\begin{array}{lll}\text { Planning Training } & \begin{array}{l}\text { Reengineering and } \\ \text { Methodology Development }\end{array}\end{array}$

Figure 2. A Planned Approach to Action Research (Parallel and Sequential)

Walls, Widmeyer, and El Sawy (1992) described the need for information system design theories in the context of executive information systems. The design of such systems is comprised of a set of requirements to address a class of problems, a description of artifacts to meet those requirements, kernel theories from the natural and social sciences, and a set of hypotheses that can be used to verify whether the design satisfies the requirements. Markus, Majchrzak, and Gasser (2002) later used action research in the production of such a design theory for emergent knowledge systems. In doing so they followed an iterative process of specifying kernel theory, developing hypotheses, implementing in-use systems, and integrating findings back into the development of new theory. Action research was, in this case, embedded within an overarching research agenda in the development of the TOP Modeler tool by Majchrzak (1997), Majchrzak and Finley (1997), and Majchrzak and Gasser (2000) as illustrated in Figure 3. Kernel theory was modified to the point where a new theory of emergent knowledge systems was provided (Markus et al. 2002). Where Walls et al. developed design theory for executive information systems, Markus et al. developed design theory for systems that support emergent knowledge processes. Where Walls et al. "used empirical evidence from over 20 case studies" (p. 49), Markus et al. "followed the action research strategy" (p. 187).

This research approach provided the involved researchers with a variety ofmethods (field observation, case study, and action research) to help explain emergent knowledge systems. The use of action research emerged as part of a larger research agenda. It was used in sequence with other methods and not as the planned and dominant methodology from the outset. The resulting design theory can subsequently be further validated, refined, and adopted to other, similar domains. Such explorations can continue the emergent process as well as strengthen and further develop the theory through field experiments, case studies, or renewed action research efforts. 


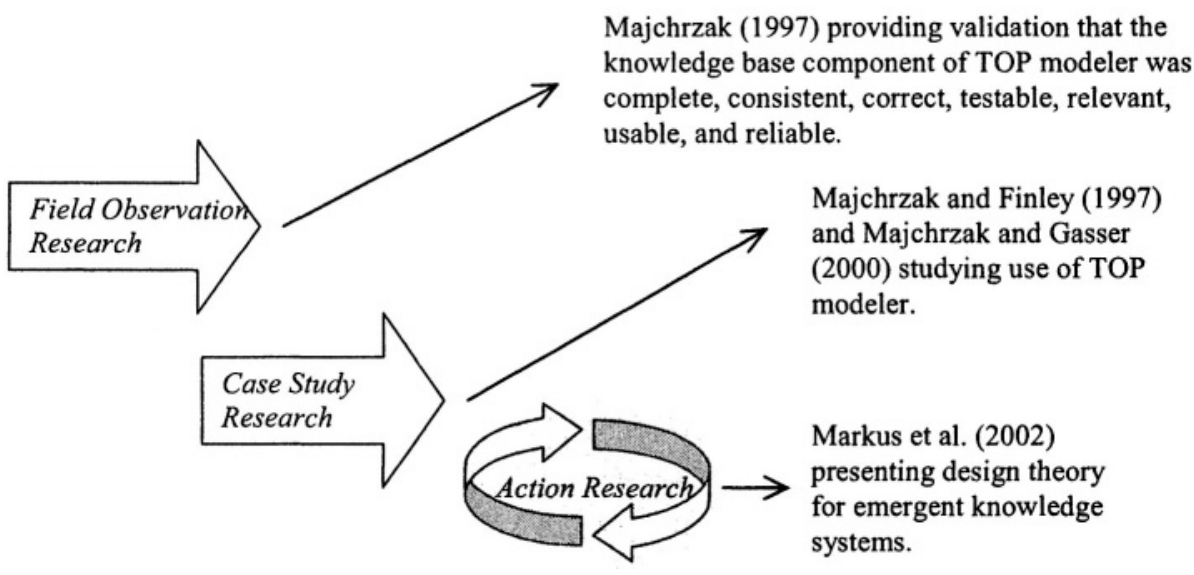

Figure 3. An Emergent Approach to Action Research (Sequential)

Iversen et al. (1999) represents a different case of emergent action research (see Figure 1). This study is embedded within a planned and dominant approach to action research (Mathiassen 2002; Mathiassen et al. 2002). The Markus et al. example illustrates how action research can emerge as a useful approach to develop theory based on findings from field observation and case studies. The Iversen et al. example illustrates how a planned and dominant approach to action research leads to a number of events and situations that present the involved researchers with new and unplanned opportunities to engage in additional explorations. Each new initiative can be pursued based on its own mix of methods including new action research efforts. For additional studies representing planned and emergent use of action research, see Appendix A.

\section{DISCUSSION}

Our studies of successful cases of Information Systems action research offer contributions to scientific knowledge within two areas. First, they further our understanding of multi-method approaches to Information Systems research. Mingers (2001) provides two reasons for adopting pluralist approaches: the multidimensional world and the complexity of research processes. This leads to a two dimensional framework for mapping research methods to practices. The one dimension distinguishes between three different worlds, the material, the personal, and the social world (Habermas 1984), inviting researchers to combine objective, subjective, and intersubjective perspectives. The second dimension distinguishes between four activities, appreciation, analysis, assessment, and action, inviting researchers to combine methods that effectively address the varying concerns and challenges involved as the research process unfolds.

Our research shows that there is a third rationale for pluralist methodology: the potential multiplicity of research contributions related to action research processes. Mingers implicitly assumes a one-to-one relationship between research process and 
outcome. Each project results in one publication. There is, however, as we have seen, in many cases a one-to-many relationship between the process and its outcome. Each research project can result in several publications and each of these can be based on different research methods or on its own mixture of methods. The multi-publication nature of research practice has two implications. It provides further arguments for adoption of pluralist methodology so a variety and mix of methods can be adopted to serve the different purposes and foci of each contribution. It also highlights the opportunity to use action research to launch additional explorations or to develop theoretical thinking based on existing findings. We suggest consequently that our rationale for and understanding of pluralist methodological opportunities in Information Systems research should be based on three concerns: Which research perspective to adopt? Which research activity to support? Which research contribution to develop?

Second, the presented research contributes to our understanding of how action research can be practiced within the Information Systems discipline. The planned and emergent approaches represent two different, yet complementary ways to consider action research. They are different as the planned approach offers an explicit way to adopt, organize, and manage Mingers' framework for multi-method research. Appreciation, analysis, assessment, and action are easily adopted and enacted through the action research cycle activities of diagnosing, action planning, action taking, evaluating, and specifying learning (Susman and Evered 1978). In the emergent approach, there is no explicit way in which Mingers' activities are enacted. Instead, Mingers' framework can be used directly to reflect on and manage the process as it unfolds. The approaches are complimentary in light of Latour's (1987) two rules of scientific method. The first rule states that scientific facts are carefully constructed from an existing domain of knowledge and that constructed facts are often debatable. Latour's second rule holds that the debate of scientific facts can result in two outcomes: the fact is either relevant or not. If the fact is relevant, it can then be reexamined in light of new methods and tools as well as being subjected to questions of authenticity and research trends. As discussed earlier, Aaen et al. (2001) used action research in a planned approach to propose a framework for examining software process improvement in organizations. From Latour's perspective, Aaen et al. addressed software process improvement as debatable, a relevant issue, and a contribution to an existing domain of knowledge. Based on the relevancy of the Aaen et al. study, subsequent projects ensued, relying on additional methods in an emergent approach to determine the authenticity of software process improvement facts in the particular context of a metrics program and to find out how these facts should be pursued (Iversen and Mathiassen 2003; Iversen et al. 1999). We believe that other lenses could also be used to illustrate how the planned and emergent approaches are used together including Lee's (1991) subjective and objective research approaches and Orlikowski and Baroudi's (1991) description of varied ontologies.

When adopted as research practices, there are important differences between the two approaches to action research. The planned approach is launched from the outset as the dominant approach and it offers a variety of opportunities to explore new issues as they emerge through the process. The emergent approach is embedded into a larger research process and it allows the researchers to explore and further develop earlier findings in practical contexts. When used as theoretical lenses to analyze research activities retrospectively, as we have done in this paper, we can use the two approaches 
interchangeably. Mathiassen et al. (2002) is presented as an example of the planned approach; but it contains a focused action research initiative (Iversen et al. 1999) that represents an example of emergent action research. Similarly, Markus et al. (2002) is presented as an emergent approach within a wider research agenda, but when viewed in isolation, represents an example of a planned approach to action research.

Our research shows that action research efforts lend themselves to pluralist methodology. First, because multiple methods help create a systematic approach to data collection that can increase the rigor of each individual contribution (Benbasat et al. 1987). Second, because action research typically is involved in multi-contribution projects where each contribution is supported by its own mix of research methods. Appreciating this provides action researchers within our discipline with action strategies that can help them develop more and better contributions from their efforts.

Pluralist methodology helps action researchers address the dilemmas (Rapoport 1970) involved in action research. The ethical dilemma (Rapoport 1970) involves biases when action researchers become too involved in the problematic situation. Such biases can be counteracted by introducing conventional approaches to data collection and analysis that help the researchers triangulate findings and arrive at more reliable results (Benbasat et al. 1987). Goal dilemmas (Rapoport 1970) can be addressed in a similar way by using conventional methods to strengthen the rigor of the research process without abandoning an interest for the problem-solving process (McKay and Marshall 2001). In addressing the initiative dilemma (Rapoport 1970), action researchers are advised to keep an open eye on emerging research opportunities during their involvement in a problematic situation and on that basis identify and execute additional research activities based on a mix of research methods. Such additional studies add to the researchers' scientific results without inducing new initiation costs, and without necessarily interfering with their involvement in practical problem solving. Pluralist strategies will, in this way, guard researchers against the major pitfalls of action research, i.e., lack of impartiality of the researcher, lack of discipline, mistaken for consulting, and difficulty of generalizing (Baskerville and Wood-Harper 1996).

Action research offers unique opportunities for Information Systems researchers to become involved in practical problem solving and to get involved in close collaboration with practitioners from our discipline. These advantages make the approach highly attractive. Action research projects involve, at the same time, complex managerial challenges. There are, however, techniques available for planning, organizing, and controlling action research projects (e.g., Avison et al. 2001; McKay and Marshall 2001) and we have here shown how multi-method thinking and practices further help researchers address the involved dilemmas and pitfalls. We argue on that basis that action research is as attractive as other conventional approaches to Information Systems research, that it offers unique opportunities to engage in research with a strong commitment to relevance, and that it is no more risky, given the right approach, than other conventional approaches within our field.

Further studies are needed to develop more specific tactics that can be adopted in action research efforts. These tactics should combine insights from planning, organizing, and managing projects (e.g., Avison et al. 2001; McKay and Marshall 2001) with pluralist research methodology. Such efforts should also explore the relationship and possible interaction between the professional methods adopted in the problem solving cycle with the mix of research methods that are adopted in the research cycle. 


\section{SUMMARY}

We have used Mingers' framework for combining Information Systems research methods to explore action research practices within our discipline. We have identified two different approaches to action research, the planned and the emergent, and we have demonstrated how the one-to-many relationship between research process and outcome that is typical for action research projects contributes to our general understanding of pluralist methodology. We have also shown that action research is supported well by pluralistic methodology and that it offers important opportunities for additional explorations and for developing theoretical thinking based on existing findings.

This paper is part of an ongoing effort to contribute to increased diversity within Information Systems research (Robey 1996). More action research, especially among the new-comers of our field, will contribute to this diversity by strengthening the position of action research and by increasing the interaction and collaboration between researchers and practitioners within our field. Also, we believe that the planned and emergent approaches exist across different methodologies and, in general, a pluralist methodology can contribute to increased diversity within each individual action research project.

\section{REFERENCES}

Aaen, I., Arent, J., Mathiassen, L., and Ngwenyama, O. "A Conceptual MAP of Software Process Improvement," Scandinavian Journal of Information Systems (13), 2001, pp. 123-146.

Andersen, I., Borum, F., Kristensen, P.H., and Karnøe, P. On the Art of Doing Field Studies, Copenhagen: Copenhagen Business School Press, 1995.

Argyris, C. Intervention Theory and Method. A Behavioral Science View, Reading, MA: Pearson Addison Wesley 1970.

Avison, D., Baskerville, R. and Myers, M. "Controlling Action Research Projects," Information Technology \& People (14:1), 2001, pp. 28-45.

Baskerville, R. L., and Stage, J. "Controlling Prototype Development Through Risk Analysis," MIS Quarterly (20:4), 1996, pp. 481-504.

Baskerville, R. L., and Wood-Harper, A. T. "A Critical Perspective on Action Research as a Method for Information Systems Research," Journal of Information Technology (11), 1996, pp. 235-246.

Baskerville, R. L., and Wood-Harper, A. T. "Diversity in Information Systems Action Research Methods," European Journal of Information Systems (7), 1998, pp. 90-107.

Benbasat, I., Goldstein, D. K., and Mead, M. "The Case Research Strategy in Studies of Information Systems," MIS Quarterly (11:3), 1987, pp. 369-386.

Boehm, B. W. "A Spiral Model of Software Development and Enhancement," Computer (21:5), 1988, pp. 61-72.

Boehm, B. W. Software Risk Management, Washington, DC: IEEE Computer Society Press, 1989.

Borum, F. Organization, Power, and Organizational Change, Copenhagen: Handelshøjskolens, Forlag, 1995.

Briggs, R. O., Adkins, M., Mittleman, D., Kruse, J., Miller, S., and Nunamaker, J. F. “A Technology Transition Model Derived from Field Investigation of GSS Use Aboard the U.S.S. CORONADO," Journal of Management Information Systems (15:3), 1998/1999, pp. 151195. 
Cassell, C., Fitter, M., Fryer, D., and Smith, L. "The Development ofComputer Applications by Non-employed People in Community Settings," Journal of Occupational Psychology (61), 1988, pp. 89-102.

Checkland, P. "From Framework Through Experience to Learning: the Essential Nature of Action Research," in H-E. Nissen, H. K. Klein, and R. H. Hirshheim (Eds.), Information Systems Research: Contemporary Approaches and Emergent Traditions, Amsterdam: North-Holland, 1991, pp. 397-403.

Davison, R. M. An Action Research Perspective of Group Support Systems: How to Improve Meetings in Hong Kong, Unpublished Doctoral Dissertation, 1998, City University of Hong Kong.

Davison, R. M. "GSS and Action Research in the Hong Kong Police Force," Information Technology and People, (14:1), 2001, pp. 60-77.

Davison, R. M. and Vogel, D. R. "Group Support Systems in Hong Kong: An Action Research Project, Information Systems Journal (10:1), 2000, pp. 3-20.

DeVreede, G. J. "Collaborative Business Engineering with Animated Electronic Meetings," Journal of Management Information Systems (14:3), 1997/1998, pp. 141-164.

Gustavsen, B. "Action Research and the Generation of Knowledge," Human Relations (46:11), 1993, pp. 1361-1365.

Habermas, J. The Theory of Communicative Action, Volume 1: Reason and the Rationalization of Society, London: Heineman, 1984.

Hult, M., and Lennung, S.- $\AA$. "Towards a Definition of Action Research: A Note and Bibliography," Journal of Management Studies (17:2), 1980, pp. 241-250.

Huxham, C., and Vangen, S. "Action Research for Understanding Collaboration Practice: Emerging Research Design Choices," in Proceedings of the $24^{\text {th }}$ International Congress of Applied Psychology, San Francisco, August 9-14, 1998a.

Huxham, C., and Vangen, S. "Leadership in the Shaping and Implementation of Collaboration Agendas: How Things Happen in a (Not Quite) Joined Up World," Academy of Management Journal (6), 2000, pp. 1159-1175.

Huxham, C., and Vangen, S. "What Makes Practitioners Tick? Understanding Collaboration Practice and Practicing Collaboration Understanding," in Proceedings of the Workshop on Interorganizational Collaboration and Conflict, Montreal, April 1998b.

Iversen, J., and Mathiassen, L. "Cultivation and Engineering of a Software Metrics Program," Information Systems Journal (13:1), 2003, pp. 3-19.

Iversen, J., Mathiassen, L., and Nielsen, P. A. "Managing Risks in Software Process Improvement: An Action Research Approach," in Proceedings of the $7^{\text {th }}$ European Conference on Information Systems, Copenhagen, Denmark, 1999, pp. 370-385.

Kinkaid, H. "Assessing Functional Explanations in the Social Sciences," in M. M. Martin and L. C. McIntyre (Eds.), Readings in the Philosophy of Social Science, Cambridge, MA: MIT Press, 1994, pp. 415-428.

Kock, N. F. The Effects of Asynchronous Groupware on Business Process Improvement, Unpublished Ph.D. Thesis, University of Waikato, New Zealand, 1997a.

Kock, N. F. "Myths in Organizational Action Research: Reflections on a Study of ComputerSupported Process Redesign Groups," Organizations \& Society (4:9), 1997b, pp. 65-91.

Kock, N. F., McQueen, R. J., and Scott, J. "Can Action Research be Made More Rigorous in a Positivistic Sense? The Contribution of an Interpretive Approach," Journal of Systems and Information Technology (1:1), 1997, pp. 1-24.

Latour, B. Science in Action: How to Follow Scientists and Engineers Through Society, Cambridge, MA: Harvard University Press, 1987.

Lau, F. "A Review on the Use of Action Research in Information Systems Studies, in A. S. Lee, J. Liebenau, and J. I. DeGross (Eds.), Information Systems and Qualitative Research, London: Chapman \& Hall, 1997, pp. 31-68. 
Lee, A. "Integrating Positivist Approaches to Organizational Research," Organization Science (2:4), 1991, pp. 342-365.

Levin, M. "Creating Networks for Rural Economic Development in Norway," Human Relations (46:2), 1993, 193-218.

Majchrzak, A. "Software to Support Socio-Technical Design: The Case of TOP-Integrator," in G. Salvendy, M. Smith and R. Koubek (Eds.), Design of Computing Systems, New York: Elsevier, 1997, pp. 229-231.

Majchrzak, A., and Finley, L. "A Practical Theory and Tool for Specifying Socio-Technical Requirements to Achieve Organizational Effectiveness," in J. Benders, J. de Haan, and D. Bennett (Eds.), The Symbiosis of Work and Technology, London: Taylor and Francis, 1995, pp. 95-116.

Majchrzak, A., and Gasser, L. "TOP Modeler," Information, Knowledge, \& Systems Management (2:1), 2000, pp. 95-110.

Markus, M. L., Majchrzak, A., and Gasser, L. "A Design Theory for Systems that Support Emergent Knowledge Processes," MIS Quarterly (26:3), 2002, pp. 179-212.

Mathiassen, L. "Collaborative Practice Research," Information, Technology \& People (15:4), 2002, pp. 321-345.

Mathiassen, L., Borum, F., and Pederson, J. S. "Developing Managerial Skills in IT Organizations: A Case Study Based on Action Learning," Journal of Strategic Information Systems (8), 1999, pp. 209-225.

Mathiassen, L., Pries-Heje, J. and Ngwenyama, O. (Eds.). Improving Software OrganizationsFrom Principles to Practice, Upper Saddle River, NJ: Addison-Wesley, 2002.

Mathiassen, L., and Stage, J. "The Principle of Limited Reduction in Software Design," Information, Technology and People (6:2), 1992, pp. 171-185.

Mathiassen, L., Seewaldt, T., and Stage, J. "Prototyping and Specifying: Principles and Practices of a Mixed Approach," Scandinavian Journal of Information Systems (7:1), 1995, 55-72.

Mingers, J. "Combining IS Research Methods: Towards a Pluralist Methodology," Information Systems Research (12:3), 2001, pp. 240-259.

McKay, J., and Marshall, P. "The Dual Imperatives of Action Rresearch," Information Technology \& People (14:1), 2001, pp. 46-59.

Orlikowski, W., and Baroudi, J. "Studying Information Technology in Organizations: Research Approaches and Assumptions," Information Systems Research (2:1), 1991, pp. 1 -62.

Pava, C. "Designing Managerial and Professional Work for High Performance: A Sociotechnical Approach," National Productivity Review (2), 1983a, pp. 126-135.

Pava, C. Managing New Office Technology: An Organizational Strategy, New York: Free Press, 1983b.

Pava, C. "Redesigning Sociotechnical Systems Design: Concepts and Methods for the 1990s," Journal of Applied Behavioral Science (22:3), 1986, pp. 201-221.

Rapoport, R. N. “Three Dilemmas in Action Research,” Human Relations (23:4), 1970, pp. 499513.

Robey, D. "Research Commentary: Diversity in Information Systems Research: Threat, Promise, and Responsibility," Information Systems Research (7:4), 1996, pp. 400-408.

Salmon, M. "Explanation in the Social Sciences," in P. Kitcher and W. Salmon (Eds.), Scientific Explanation; Minnesota Studies in the Philosophy of Science, Minneapolis, MN: University of Minnesota Press, 1989, pp. 385-409.

Smith, L., Fryer, D. M., and Fritter, M. J. "A Study of Computing Needs of Wageless People in Sheffield," Medical Research Council/Economic and Social Research Council, and Social and Applied Psychology Memo 708, University of Sheffield, 1985.

Susman, G. I., and Evered, R. D. "An Assessment of the Scientific Merits of Action Research," Administrative Science Quarterly (23), 1978, pp. 582-603.

van Fraassen, B. C. The Scientific Image, Oxford University Press, 1980. 
VanMannen.J. Tales from the Field: On Writing Ethnography, Chicago: University of Chicago Press, 1988.

Vangen, S. Transferring Insight on Collaboration into Practice" Unpublished Doctoral Dissertation, University of Strathclyde, Glasgow, 1998.

Vangen, S., and Huxam, C. "Creating a Tip: Issues in the Design of a Process for Transferring Theoretical Insight about Inter-Organizational Collaboration into Practice," International Journal of Public-Private Partnerships (1:1), 1998, pp. 19-42.

Walls, J. G., Widmeyer, G. R., and El Sawy, O. A. "Building an Information System Design Theory for Vigilant EIS," Information Systems Research (3:1), 1992, pp. 36-59.

Walsham, G. "The Emergence of Interpretivism in IS Research," Information Systems Research (6:4), 1995, pp. 376-394.

Ytterstad, P., Akselsen, S., Svendsen,G. and Watson, R. T. "Teledemocracy: Using Information Technology to Enhance Political Work," MISQ Discovery, 1996.

\section{ABOUT THE AUTHORS}

Matt Germonprez holds a Ph.D. in Information Systems from the University ofColorado at Boulder and is currently an assistant professor at Case Western Reserve University. His research interests focus on computer mediated communication and human-computer interaction. In particular, he is interested in how information technology can be built to support end-user modifications in the context of use. His work draws from the domains of information systems, computer science, and the philosophy of science. Matt can be reached at Germonprez@ CWRU.edu.

Lars Mathiassen holds an M.Sc. in computer science from Århus University, Denmark, a $\mathrm{Ph} . D$. in Informatics from Oslo University, Norway, and a Dr. Techn. in software engineering from Aalborg University, Denmark. He is currently Georgia Research Alliance Eminent Scholar and Professor in Computer Information Systems at Georgia State University. His research interests focus on engineering and management of IT systems. More particularly, he has worked with project management, object-orientation, organizational development, management of IT, and the philosophy of computing. He has co-authored several books, including Professional Systems Development-Experiences, Ideas and Action, Computers in Context: The Philosophy and Practice of Systems Design, Object-Oriented Analysis \& Design, and Improving Software Organizations: From Principles to Practice. Lars can be reached at Lars.Mathiassen@ eci.gsu.edu. 


\section{Appendix A}

\section{Additional Planned and Emergent Cases ${ }^{1}$}

\begin{tabular}{|c|c|}
\hline Planned Use of Action Research & Illustrative Quote \\
\hline $\begin{array}{l}\text { Kock (1997a): Action research was } \\
\text { used to investigate the effects of } \\
\text { asynchronous groupware on total } \\
\text { quality management and business } \\
\text { process reengineering. Action research } \\
\text { was a planned approach as iterations } \\
\text { through the action research cycle } \\
\text { framed subsequent action research. }\end{array}$ & $\begin{array}{l}\text { "The fourth iteration in the AR cycle dis- } \\
\text { seminated all the software applications, pre- } \\
\text { viously introduced only locally, throughout the } \\
\text { organization. These subsequent iterations } \\
\text { generated new hypotheses, reinforced former } \\
\text { ones, and also provided ground for refutation of } \\
\text { some previous hypotheses" (Kock et al. 1997, } \\
\text { p. 15). }\end{array}$ \\
\hline $\begin{array}{l}\text { DeVreede (1997/1998): Group support } \\
\text { systems and animation techniques were } \\
\text { used in support of user involvement and } \\
\text { organizational change processes. } \\
\text { Action research was used as a planned } \\
\text { approach within which survey } \\
\text { instruments and case study interviews } \\
\text { were used to determine perceived } \\
\text { session quality and satisfaction. }\end{array}$ & $\begin{array}{l}\text { "During the study, both quantitative and } \\
\text { qualitative data from various sources were } \\
\text { collected to enable a rich representation of the } \\
\text { phenomena under investigation and to permit } \\
\text { comparison and contrast of the collected } \\
\text { data....Quantitative data sources included } \\
\text { system logs of each session and questionnaires } \\
\text { completed by the participants after each [action } \\
\text { research intervention], and our ongoing } \\
\text { observations during each session and during the } \\
\text { [case] study as a whole" (p. 144). }\end{array}$ \\
\hline $\begin{array}{l}\text { Pava (1986): Action research was used } \\
\text { in the investigation of concepts in the } \\
\text { design of socio-technical information } \\
\text { systems for nonlinear decision pro- } \\
\text { cesses. Action research was a planned } \\
\text { approach to frame a traditional case } \\
\text { study of socio-technical systems. }\end{array}$ & $\begin{array}{l}\text { "[Embedded in an action research agenda], the } \\
\text { social analysis [of the case study] was based on } \\
\text { interviews of current and former employees and } \\
\text { on longitudinal analysis of human resource } \\
\text { data." (p. 212). }\end{array}$ \\
\hline $\begin{array}{l}\text { Mathiassen, Borum, and Pedersen } \\
\text { (1999): The interaction between } \\
\text { individual learning and organizational } \\
\text { context was studied in realtion to an } \\
\text { action learning program. Action } \\
\text { research was used in a planned ap- } \\
\text { proach in conjunction with a traditional } \\
\text { case study in the development, execu- } \\
\text { tion, and assessment of an in-house } \\
\text { program for educating furture IT } \\
\text { managers in a Danish company. }\end{array}$ & $\begin{array}{l}\text { "Our different roles as consultants, trainers, and } \\
\text { observers made possible a blend of action } \\
\text { research (Argyris 1970; Borum 1995), partici- } \\
\text { pant observation (Van Maanen 1988; Andersen } \\
\text { et al. 1995), and traditional case study data } \\
\text { generation (Yin 1994). This combined ap- } \\
\text { proach provides a rich insight into organiza- } \\
\text { tional phenomena and allows for validation and } \\
\text { triangulation between different types of data." } \\
\text { (pg 439). }\end{array}$ \\
\hline
\end{tabular}

${ }^{1}$ The cases in this table and those presented in the literature were compiled from Lau (1997) and Michael Myers' Qualitative Research Methods page at http://www.isworld.org, as well as cited papers in published action research studies. 


\begin{tabular}{|c|c|}
\hline Planned Use of Action Research & Illustrative Quote \\
\hline $\begin{array}{l}\text { Ytterstad, Akselsen, Svendsen, and } \\
\text { Watson (1996): Technology was used } \\
\text { to address problems surrounding the } \\
\text { fact that many politicians do not seek } \\
\text { reelection in Norway. Action research } \\
\text { was used in a planned approach to } \\
\text { determine how politicians used tech- } \\
\text { nology to support daily activities and to } \\
\text { frame a field trial in the investigation of } \\
\text { information technology use in } \\
\text { Norwegian politics. }\end{array}$ & $\begin{array}{l}\text { "[The research project] is a cyclic process of } \\
\text { investigation that includes the identification and } \\
\text { diagnosis of a problem, planning of actions, } \\
\text { implementation, and evaluation of results...to } \\
\text { analyze political work in terms of content, } \\
\text { communication patterns, workload patterns, and } \\
\text { advantages and drawbacks as perceived by the } \\
\text { politicians. This [analysis] included the } \\
\text { following activities: [interviewing, analyzing a } \\
\text { questionnaire, analyzing formal documents, } \\
\text { analyzing telephone utilization]" (The Project } \\
\text { section) }\end{array}$ \\
\hline $\begin{array}{l}\text { Briggs, Adkins, Mittleman, Kruse, } \\
\text { Miller, and Nunamaker (1998/1999): } \\
\text { The technology acceptance model was } \\
\text { investigated with respect to GSS use. A } \\
\text { new model of technology transition is } \\
\text { proposed. Action research was used as } \\
\text { in a planned approach in parallel with a } \\
\text { field study. }\end{array}$ & $\begin{array}{l}\text { "This article presents a } 32 \text { month field } \\
\text { investigation of an effort to introduce GSS into } \\
\text { the daily work processes of the staff of the US } \\
\text { Navy's Third Fleet aboard the USS } \\
\text { CORONADO. The principles of action } \\
\text { research guided the investigation....The project } \\
\text { began with [action research] interventions } \\
\text { based on the precepts of Davis' [TAM]" (p. } \\
\text { 154). }\end{array}$ \\
\hline Emergent Use of Action Research & Illustrative Quote \\
\hline $\begin{array}{l}\text { Baskerville and Stage (1996): Risk } \\
\text { analysis was shown to be an important } \\
\text { component in the prototyping of } \\
\text { information systems. Action research } \\
\text { was used in an emergent approach as it } \\
\text { built on the work of Mathiassen and } \\
\text { Stage (1992) - (Literature Review/ } \\
\text { Observation) and Mathiassen, Seewaldt, } \\
\text { and Stage (1995) (Experimental) in the } \\
\text { development and evaluation of } \\
\text { technology prototyping. }\end{array}$ & $\begin{array}{l}\text { "The third stream of literature [used by } \\
\text { Baskerville and Stage 1996] is concerned with } \\
\text { general software development frameworks } \\
\text { (Boehm 1988, 1989)....The definition of } \\
\text { [framework] factors originates from theoretical } \\
\text { work (Mathiassen and Stage 1992) that has } \\
\text { been further explored in more recent empirical } \\
\text { studies (Mathiassen et al. 1995)" (p. 485). }\end{array}$ \\
\hline $\begin{array}{l}\text { Cassell, Fitter, Fryer, and Smith } \\
\text { (1988): Three community groups were } \\
\text { examined in the implementation of } \\
\text { information technology to unemployed } \\
\text { individuals. The SPRITE project } \\
\text { [action research] was successful in } \\
\text { teaching computing skills that were } \\
\text { translated to jobs and the exchange of } \\
\text { community information. }\end{array}$ & $\begin{array}{l}\text { "..three community groups consisting of non- } \\
\text { employed people were selected as instances of } \\
\text { differing autonomous collectives. Non- } \\
\text { directive discussions were held in each of the } \\
\text { centres on the theme of the relevance of new } \\
\text { technology to the group concerned. } \\
\text { Discussions were tape-recorded and content- } \\
\text { analysed. Analyses were then fed back to each } \\
\text { of the groups and a final version negotiated (see } \\
\text { Smith, Fryer, and Fritter 1985)" (p. 92). }\end{array}$ \\
\hline
\end{tabular}




\begin{tabular}{|c|c|}
\hline Emergent Use of Action Research & Illustrative Quote \\
\hline $\begin{array}{l}\text { Pava (1986): New concepts need to be } \\
\text { developed in the design of socio- } \\
\text { technical information systems. Systems } \\
\text { need to support an inherent flexibility, } \\
\text { as organizations move away from } \\
\text { hierarchical structure in support of } \\
\text { nonlinear processes. Action research is } \\
\text { used in sequence with prior work on the } \\
\text { development of socio-technical systems } \\
\text { in the support of nonlinear work. }\end{array}$ & $\begin{array}{l}\text { "To overcome deficiencies of socio-technical } \\
\text { system design, alternate approaches must be } \\
\text { developed. One has been proposed based on } \\
\text { action research projects in nonlinear work } \\
\text { systems (Pava 1983a; b). This approach } \\
\text { emphasizes new concepts redefining the basic } \\
\text { units of social and technical analysis. It also } \\
\text { identities alternatives other than the } \\
\text { autonomous work group that can also yield a } \\
\text { 'best match' between an organization and its } \\
\text { technology" (p. 206). }\end{array}$ \\
\hline $\begin{array}{l}\text { Huxham and Vangen (2000): Leader- } \\
\text { ship roles play a part in collaborative } \\
\text { agenda implementation. Ultimately, } \\
\text { collaboration stems from leadership } \\
\text { structures, processes, and individuals. } \\
\text { Action research was used to contribute } \\
\text { to prior empirical research and } \\
\text { strengthen the theory of collaboration in } \\
\text { social settings. }\end{array}$ & $\begin{array}{l}\text { "This research forms an element of a program } \\
\text { that has so far spanned ten years and that is an } \\
\text { effort to develop practice-oriented theory on the } \\
\text { management of collaboration (Huxham and } \\
\text { Vangen 1998a; 1998b; Vangen 1998; Vangen } \\
\text { and Huxham 1998). The program is rooted, to } \\
\text { a very large extent, in action research" (p. } \\
\text { 1161). }\end{array}$ \\
\hline
\end{tabular}

